\title{
Penyuluhan Mengenal Stunting dan Efeknya pada Pertumbuhan Anak
}

\author{
Nurgadima Achmad Djalaluddin \\ Universitas Sulawesi Barat, Jalan Prof. Dr. Baharuddin Lopa, Kabupaten Majene, Indonesia, 91412 \\ *e-mail: nurgadima@unsulbar.ac.id
}

\begin{abstract}
Abstrak
Program kemitraan masyarakat (PKM) ini melibatkan Puskesmas Totoli, Kabupaten Majene, Kecamatan Banggae sebagai penanggung jawab wilayah kerja dan Posyandu Samusenga'na Desa Palipi Soreang, Kecamatan Banggae, Kabupaten Majene yang memiliki sasaran kegiatan. Secara umum tujuan progran PKM ini untuk mengetahui tingkat pengetahuan dan pemahaman masyarakat sasaran tentang stunting dan efeknya pada pertumbuhan anak. Target khusus melalui kegiatan ini adalah untuk mengurangi angka stunting yang ada di wilayah Puskesmas Totoli khususnya di Posyandu Samusenga'na. Metode yang digunakan dalam pencapaian tujuan adalah penyuluhan dengan metode ceramah tanya jawab (CTJ) kepada sasaran dan kader Posyandu Samusenga'na Desa Palipi Soreang, Kecamatan Banggae. Hasil dari kegiatan PKM diharapkan sesuai tujuan dan target yang diliat dari peran aktif peserta selama kegiatan berlangsung.
\end{abstract}

Kata Kunci : Posyandu, Penyuluhan, Stunting, dan Efek terhadap Pertumbuhan

\section{Pendahuluan}

Stunting adalah sebuah kondisi dimana tinggi badan seseorang ternyata lebih pendek dibanding tinggi badan orang lain pada umumnya atau seusianya (Kementerian Desa, 2017). Menurut Keputusan Menteri Kesehatan Nomor 1995/MENKES/SK/XII/2010 tentang Standar Antropometri Penilaian Status Gizi Anak, pengertian pendek dan sangat pendek adalah status gizi yang didasarkan pada indeks Panjang Badan menurut Umur (PB/U) atau Tinggi Badan menurut Umur (TB/U) yang merupakan padanan istilah stunted (pendek) dan severely stunted (sangat pendek). Balita pendek (stunting) dapat diketahui bila seorang balita sudah diukur panjang atau tinggi badannya, lalu dibandingkan dengan standar, dan hasilnya berada di bawah normal (Pusdatin Kemenkes RI, 2016).

Penyebab stunting antara lain : 1) Faktor gizi buruk yang dialami oleh ibu hamil maupun anak balita. 2). Kurangnya pengetahuan ibu mengenai kesehatan dan gizi, sebelum dan pada masa kehamilan, serta setelah ibu melahirkan. 3). Masih terbatasya layanan kesehatan. 4). Masih kurangnnya akses kepada makanan bergizi dan 5). Sanitasi yang tidak layak dan kurangnya akses air bersih.

Stunting merupakan permasalahan kesehatan yang saat ini dihadapi oleh negara

berkembang. Menurut United Nation International Childrens Emergency Fund (UNICEF) satu dari 3 (tiga) anak mengalami stunting dan sekitar $40 \%$ anak di daerah pedesaan mengalami pertumbuhan terhambat. Sebanyak 159 juta anak stunting di seluruh dunia (Bank Dunia, 2016).

Hasil Riset Kesehatan Dasar 2013 menunjukkan bahwa Provinsi Sulawesi Barat menduduki peringkat kedua angka stunting tertinggi yaitu 48,02\% setelah Provinsi Nusa Tenggara Timur 51,73\% (Kemenkes RI 2013). Data Pemantauan Status Gizi (PSG) tahun 2016 menunjukkan angka stunting di Provinsi Sulawesi Barat tertinggi yaitu 39,7\% (Dinkes Prov. Sulbar, 2016) dan tahun 2017 menduduki peringkat kedua yaitu 40,1\% dan Kabupaten Majene menduduki peringkat kedua angka stunting tertinggi yaitu 43,8\% di Provinsi Sulawesi Barat (Dinkes Prov. Sulbar, 2017). Data Tahun 2018 untuk wilayah Puskesmas Totoli yaitu 45,149\% dan Desa Palipi Soreang yaitu 54,217 (Dinkes Kab. Majene Prov. Sulbar 2018).

Posyandu merupakan salah satu bentuk Upaya Kesehatan Bersumberdaya Masyarakat (UKBM) yang dikelola dari, oleh, untuk, dan bersama masyarakat, guna memberdayakan masyarakat dan memberikan kemudahan kepada masyarakat dalam memperoleh pelayanan kesehatan dasar. (Kementrian Kesehatan RI Pusat Promosi Kesehatan Tahun 2012). Dari uraian di atas maka di pandang perlu untuk melakukan kegiatan penyuluhan Di Posyandu Samusenga'na Desa Palipi soreang wilayah Puskesmas Totoli Kabupaten Majene mengingat angka kejadian stunting di Desa tersebut masih tinggi. 


\section{Metode Pelaksanaan}

Metode yang akan digunakan dalam pelaksanaan kegiatan pemberdayaan ini berupa ceramah tanya jawab (CTJ), adapun tahapan-tahapannya adalah :

1. Pelaksanaan pengabdian masyarakat melakukan kunjungan ke Puskesmas Totoli Kec. Banggae Kab. Majene Metode untuk memperkenalkan rencana kegiatan kemitraan masyarakat dengan menjelaskan secara detail kegiatan yang akan dilaksanakan dan dilakukan diskusi maka diperoleh kesepakatan bersama untuk menunjuk Posyandu Samusenga'na Dusun Labu-Labuang Desa Palipi Soreang di wilayah Puskesmas Totoli untuk dilaksanakan penyuluhan sesuai permasalahan yang ada dalam proposal ini. Tahap ini dibuat pada kesepakatan pengaturan rencana kegiatan dan jadwal pelaksanaan pengabdian masyarakat sehingga komitmen untuk mengikuti dan berpartisipasi aktif lebih tinggi demi kelancaran penyuluhan ini.

2. Mekanisme pelaksanaan kegiatan penyuluhan sebagai berikut :

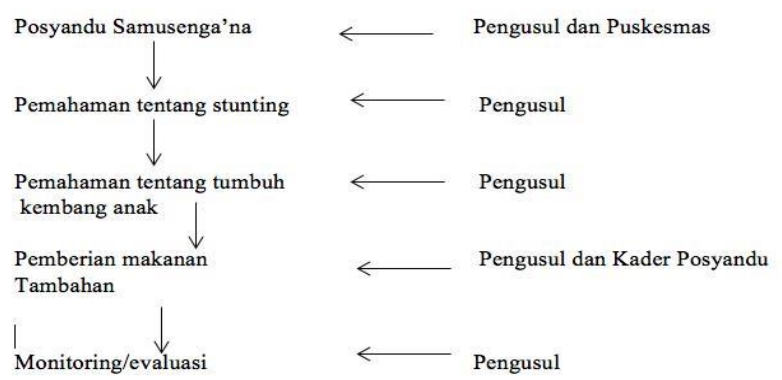

\section{Hasil}

1. Karakteristik Peserta

Peserta penyuluhan adalah sasaran dari Posyandu Samusenga'na Desa Palipi Soreang Kecamatan Banggae

Kabupaten Majene. Peserta mampu menerima materi yang diberikan tentang Mengenal Stunting dan Efeknya pada

Pertumbuhan Anak.

2. Respon peserta

Respon peserta sangat baik terbukti dengan antusiasnya dalam memberikan pertanyaan dan berbagi pengalaman. Sebagian peserta tidak mengetahui tentang stunting dan pola asuh anak dan mereka sangat mengharapkan kegiatan ini bisa berlanjut setiap hari posyandu.

3. Dampak

Dampak yang ditimbulkan dari kegiatan ini adalah:

a. Peserta yang mengikuti kegiatan ini sudah mengetahui dan memahami tentang stunting dan efeknya pada pertumbuhan anak.

b. Dengan penyuluhan yang dilakukan kepada sasaran di Posyandu Samusenga'na bukan hanya akan berdampak pada sasaran posyandu tapi juga di masyarakat pada umumnya.

\section{Kesimpulan}

Berdasarkan kegiatan pengabdian kepada masyarakat ini dapat disimpulkan bahwa senam diabetes dapat membantu penderita diabetes melitus dalam mengontrol kadar glukosa dalam darah sehingga kualitas hidup penderita diabetes melitus yang berada di RW 001 \& RW 002 Kelurahan Katimbang Kecamatan Biringkanaya Kota Makassar dapat meningkat dengan terkendalinya glukosa darah penderita

\section{Daftar Pustaka}

Cahyono F, M.S.. dan P.I., 2016. Faktor Penentu Stunting Anak Balita pada Berbagai Zona Ekosistem di Kab. Kupang. , 11(1), pp.9-18.

DinkesProv. Sulbar，2016. Pemantauan Status Gizi (PSG) 2016.

Dinkes Prov. Sulbar, 2017. Pemantauan Status Gizi 2017.

Kemendes, P.D.T. dan Transmigrasi, 2017. Buku Saku Desa dalam Penanganan Stunting, Jakarta. 

pISSN : 2622-9595 eISSN : 2623-0097

Kemenkes RI, 2013. Riset Kesehatan Dasar 2013.

Pusdatin Kemenkes RI, 2016. Situasi Balita Pendek 2016.

Kemenkes, RI. 2012. Buku Saku Posyandu: Jakarta 